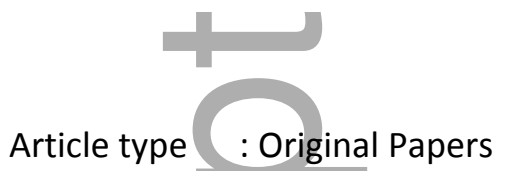

\title{
Acute flaccid myelitis in childhood: A retrospective cohort study
}

Erik W Andersen FRACP ${ }^{1,2}$; Andrew J Kornberg FRACP ${ }^{1}$; Jeremy L Freeman FRACP $^{1,3}$;

Richard J Leventer $\mathrm{PhD}^{1,3,4}$; Monique M Ryan FRACP ${ }^{1,3,4}$

${ }^{1}$ Department of Neurology, The Royal Children's Hospital, Melbourne, Victoria, Australia; ${ }^{2}$ Department of Paediatrics and Child Health, University of Otago Wellington, Wellington, New Zealand;

${ }^{3}$ Murdoch Children's Research Institute, Melbourne, Victoria, Australia;

${ }^{4}$ Department of Paediatrics, University of Melbourne, Melbourne, Victoria, Australia.

\section{Study Institution:}

The Royal Children's Hospital Melbourne

50 Flemington Rd

Parkville VIC 3052

Australia

\section{Corresponding Author:}

Dr Erik Andersen

Department of Paediatrics and Child Health

University of Otago Wellington

P.O. Box 7343

This is the author manuscript accepted for publication and has undergone full peer review but has not been through the copyediting, typesetting, pagination and proofreading process, which may lead to differences between this version and the Version of Record. Please cite this article as doi: $10.1111 /$ ene.13345

This article is protected by copyright. All rights reserved 
Wellington South

New Zealand

Email: erik.andersen@ccdhb.org.nz

Telephone: +64 43855999

Fax: +6443855856

Running Title: Acute flaccid myelitis in childhood: A retrospective cohort study

\section{Disclosures:}

Dr. Andersen reports grants from CSL Neuromuscular Fellowship, outside the submitted work.

Dr. Kornberg reports grants from National Health and Medical Research Council Centre for Research Excellence in Neuromuscular Disorders (Grant I.D. 1031893), outside the submitted work.

Dr. Freeman has nothing to disclose.

Dr. Leventer reports grants from Melbourne Children's Clinician Scientist Fellowship, outside the submitted work.

Dr. Ryan reports grants from National Health and Medical Research Council Centre for Research Excellence in Neuromuscular Disorders (Grant I.D. 1031893), outside the submitted work.

There are no conflicts of interest to declare. This research did not receive any specific grant from funding agencies in the public, commercial, or not-for-profit sectors.

\section{Contributors' Statements:}

Erik W Andersen: Dr Andersen acted as the Principal Investigator, performed the review of the literature, drafted the initial manuscript and approved the final manuscript as submitted. Andrew J Kornberg: Associate Professor Kornberg provided cases for review, reviewed and revised the manuscript and approved the final manuscript as submitted.

Jeremy L Freeman: Dr Freeman provided a case for review, reviewed and revised the manuscript and approved the final manuscript as submitted. 
Richard J Leventer: Dr Leventer provided cases for review, reviewed and revised the manuscript and approved the final manuscript as submitted.

Monique M Ryan: Professor Ryan coordinated the review of the cases, critically reviewed the manuscript and approved the final manuscript as submitted.

All authors approved the final manuscript as submitted and agree to be accountable for all aspects of the work.

\section{Keywords:}

Myelitis, Enterovirus, Cohort study, Poliomyelitis, Neurology, Weakness, Flaccid

\section{Abstract:}

Background: Clusters of acute limb weakness in paediatric patients have been linked to outbreaks of non-polio enteroviruses, termed acute flaccid myelitis (AFM). Outside these clusters, in countries where polio is not endemic, this poliomyelitic-like illness is rare in childhood and its natural history is not well defined. We describe presenting features, investigation findings and long-term outcome of a series of children with AFM.

Methods: Retrospective cohort study.

Results: Eight children (6 females) aged 3 months to 8 years (median age 5 years) met case criteria. Initial symptoms were pain $(n=7)$ followed by limb weakness with hypotonia $(n=8)$. Flaccid paralysis occurred in only three patients. Two had cranial nerve dysfunction. Magnetic resonance imaging of the spinal cord demonstrated gray matter involvement particularly affecting the anterior cord, with longitudinally extensive changes in three children. CSF examination showed pleocytosis in six children with raised CSF protein in five. Nerve conduction and electromyography findings were consistent with a motor neuronopathy. Residual deficits were common, with moderate-severe weakness seen in five patients. Median follow-up was 28 months (range 17-108 months, 30.4 total patient years).

Conclusion: AFM is an uncommon condition in childhood with a high rate of significant long-term morbidity. AFM should be considered in children presenting with acute limb pain and weakness. 


\section{Introduction:}

In the post-polio vaccination era, acute flaccid paralysis (AFP) has become associated with a host of diagnoses, including spinal cord tumors, trauma, transverse myelitis (TM), GuillainBarré syndrome (GBS), and less common conditions such as botulism and porphyria. Infection remains an important cause of AFP, with flaviviruses, herpesviruses, adenoviruses and enteroviruses (EV) all causing this syndrome in the developed and developing world. The outbreak of respiratory illnesses caused by EV68 in the United States and Canada in 2014 coincided with a cluster of myelitic disease $[1,2]$ termed 'acute flaccid myelitis' (AFM) by the Centre for Disease Control (CDC) [3], raising concerns about an epidemic of non-polio myelitis. Similar outbreaks of EV71 infections were described in Australia in 2013 [4].

AFM is typified by weakness and hypotonia in one or more limbs, with sensation and autonomic function being spared (in contrast to TM, in which sensory deficits and autonomic dysfunction are common). Weakness may be incomplete. Magnetic resonance imaging (MRI) of the spine demonstrates gray matter involvement with a predilection for the anterior horns, with or without concomitant brainstem involvement [2]. In severe cases longitudinally extensive myelitis can lead to respiratory failure and death. Long term outcomes are thought to be poor, although there is limited data on the natural history of this condition.

Cerebrospinal fluid (CSF) examination frequently demonstrates a pleocytosis and raised protein, while neurophysiological assessment suggests a motor neuronopathy [2].

Most cohorts occur in the context of viral outbreaks. We present a cohort of children with sporadic AFM with the objective of describing their presenting symptoms, investigation findings and long-term outcome.

\section{Methods}

We ascertained a retrospective cohort of children presenting with AFM to the Royal Children's Hospital Melbourne between 2001-2014 with the consent of the hospital ethics committee and reviewed their prospectively collected data. The Royal Children's Hospital is the largest paediatric hospital in Victoria, Australia, with more than 355,000 patient visits per year (outpatient visits and inpatient admissions). AFM was defined as an acute onset of limb weakness with an MRI showing a spinal cord lesion largely restricted to gray matter and 
spanning one or more spinal segments [5]. Children with spinal cord trauma or malignancies were excluded.

Children were investigated with a standardised protocol for myelitis. Investigations for infectious causes included blood cultures, serology for mycoplasma, cytomegalovirus, Epstein-Barr virus, herpes simplex virus (HSV) and varicella zoster virus. CSF examination included biochemical testing, bacterial culture and polymerase chain reaction (PCR) testing for HSV and EV. Stool samples were sent for viral cultures and PCR for EV and adenovirus. Where respiratory symptoms were present, nasopharyngeal aspirates or throat swabs for viral PCR arrays were performed. Flaviviruses are not seen in Victoria and were not routinely tested for.

Blood tests including full blood counts, urea and electrolytes, C-reactive protein, erythrocyte sedimentation rates, anti-nuclear antibody testing, vitamin D testing, neuromyelitis optica (NMO) IgG antibodies (for cases presenting after 2006, when testing became available) and angiotensin-converting enzyme levels were performed in all patients. Paired serum and CSF oligoclonal bands were sent where CSF was obtained.

MR imaging of the brain and spine was done at $1.5 \mathrm{~T}$ or $3.0 \mathrm{~T}$, with intravenous gadolinium contrast being given in all cases. Nerve conduction studies (NCS) and electromyography (EMG) were performed according to standard techniques [6].

\section{Results}

Eight children met the case definition above. All were residents of Victoria, Australia. The median age at presentation was 5 years (see Table 1). Recent prodromal illnesses were identified in all cases, occurring a median of three days prior to the onset of the weakness. Five children had upper respiratory tract infections (URTIs), two with exacerbation of previously-diagnosed asthma. Four of the eight children also reported additional (presumed viral) URTIs 2-6 weeks prior to the proximal prodromal illness.

For seven children (87.5\%), the initial neurological symptom was limb pain, followed within 48 hours by weakness which progressed in all children to maximal disability over 4-72 hours. Three children presented with a true flaccid paralysis, while five developed a moderate to severe monoparesis (grade 3 or weaker on the Medical Research Council Scale for Muscle Strength [7]) in at least one muscle group in the most affected extremity. In three cases the contralateral limb was also affected to a lesser degree. Two children had cranial nerve 
involvement. The deep tendon reflexes were depressed or absent in the affected limbs, but were normal elsewhere in all cases. Sensory and autonomic involvement was not seen.

All children received their diagnosis of AFM at their clinical nadir, after a variable duration of neurological symptoms (range 4 hours-127 days, median 9 days). Three children were initially thought to have psychogenic weakness, and one had been investigated for an irritable hip and occult fracture before referral. The child with the longest time to diagnosis (127 days) was initially diagnosed with transverse myelitis.

Magnetic resonance imaging of the brain and spine was undertaken in all cases, and showed abnormalities in the spinal gray matter, predominantly affecting the anterior horn (see Figure 1 and Table 2). Hyperintensity in T2-weighted sequences was seen in these regions, extending over two or more vertebral levels in all but one case (Case 5, imaged $>3$ months after the onset). On post-contrast sequences, the gray matter lesions showed enhancement in three cases, with ventral nerve root enhancement also being seen in three cases. T2-weighted imaging revealed hyperintensity within the dorsal pons and medulla in the two cases with cranial nerve involvement.

CSF examination was performed in seven children. One had a traumatic tap. The others demonstrated a mild to moderate pleocytosis with a modest lymphocytosis seen in four and increased protein in five (see Table 2).

NCS were performed in six cases (see Table 2). Concentric needle EMG was abnormal in all five subjects studied, showing decreased recruitment and motor unit action potential abnormalities consistent with a motor neuronopathy.

Evidence of acute infection was found only in case 8, who had a positive stool PCR for EV71. Case 2 was travelling in Southeast Asia at the onset of her illness, so investigations to exclude malaria, Dengue fever, Chikungunya virus and West Nile virus were performed; all were negative. Case 2 had mycoplasma-specific IgM detected via an enzyme immune assay, however mycoplasma was not cultured from any specimen, specific antibodies were equivocal via particle agglutination and no convalescent sample was obtained, so the significance of this finding was questionable. All other testing for infectious aetiologies were negative, and other investigations demonstrated no evidence of NMO, neurosarcoidosis and multiple sclerosis. 
Treatment varied between children based on clinician preference and the timing of the diagnosis. Intravenous immunoglobulin (IVIg) $2 \mathrm{~g} / \mathrm{kg}$ and/or IV methlypredinsolone $(15 \mathrm{mg} / \mathrm{kg} /$ day for 3-5 days followed by an oral taper) was administered. Case 5 received no treatment for neuro-inflammation as she was initially managed and investigated for a suspected orthopaedic cause of reduced lower limb movement. The diagnosis of myelitis was not made until 77 days after the initial symptoms and it was felt immunotherapy would not alter the course. Case 6 was managed for transverse myelitis with methylprednisolone at her initial presentation; her final diagnosis of AFM was not made until 127 days later.

The eight children were followed for a median of 28 months (range 17-108 months; 30 patient years in total). Functional outcomes varied (see Table 1). Two children had a persistent flaccid paralysis with no improvement. All children with bilateral limb involvement had complete recovery in the less affected limb. Maximal recovery was achieved by a median of 6 months (range 1-24 months).

\section{Discussion}

This cohort of patients with AFM describes the presentation and outcome of this rare condition and demonstrates, with long term follow up in comparison to previous studies, that persistent sequelae are common. These findings are consistent with other reported cohorts with shorter follow up periods. Most children in this series were left with ongoing weakness of the primarily affected limb, but cranial nerve and other limb involvement resolved.

Recovery was generally complete by six months, but could progress for as long as two years. The extent of final recovery was not predicted by age or by severity at presentation.

The pathogenesis of AFM is uncertain. Histopathological data in this setting is not available. Direct CNS invasion has been seen in enteroviral encephalomyelitis [8], but it is not clear whether AFM reflects infectious or post/para-infectious inflammation. MRI changes in the brain stem and spine are seen with viral infections, but may also be present in autoimmune conditions. In other series, viral aetiologies were not identified in many patients, with the association with EV being inferred due to clusters of cases occurring during EV epidemics [2], so it is unsurprising infectious aetiologies were frequently not identified here. Also, due the considerable variation in time to presentation to the neurology service, some investigations were performed outside the optimal time frame, perhaps further explaining the paucity of identifiable infectious agents. 
The place of immunotherapy for AFM is unclear. Corticosteroids are the standard of care in TM, in which they have been shown to reduce disability and improve outcomes [9]. There were early reports of possible benefits of corticosteroid treatment during the acute paralytic phase of poliomyelitis [10], but these were counterbalanced by animal studies demonstrating worsening infections in animals inoculated with polio in the presence of corticosteroids [11]. More recent observational data has suggested possible benefits from corticosteroid therapy in enteroviral and flavivial infections $[12,13]$, however randomised control trials are not available and are unlikely to be obtainable. There is also no experimental evidence supporting the use of intravenous immunoglobulin in this context, however pathological data from fatal encephalomyelitis cases [14] suggests that inflammation may be a modifiable factor in this pathology, and observational data of patients presenting with neurological complications of EV supports its use [4]. Current recommendations from the CDC are for supportive therapy only [3]. In this series, children were treated with intravenous immunoglobulin, corticosteroids or both, but the efficacy of these interventions could not be assessed.

In 1974, Hopkins reported 10 children seen in a single centre between 1968 and 1974 with polio-like symptoms 4-7 days after URTIs with symptoms of asthma [15]. Children presented with weakness and pain affecting one or more limbs, hypotonia, CSF pleocytosis, raised CSF protein level, and neurophysiologic findings suggestive of a neuronopathy, a conclusion supported by MRI of subsequent cases [16]. Several subsequent reports of Hopkins syndrome have been linked to various infections, including EV [17].

The similarities between the cases in this cohort and the previously described patients with Hopkins syndrome are striking. Two of the children in this cohort had illnesses consistent with the clinical syndrome described by Hopkins. These entities are likely variants of the same condition, as are recently described cases in adults with HIV [18].

The retrospective nature of this analysis makes it difficult to estimate the prevalence of sporadic AFM due to ascertainment bias. Categorisation of cases relied on clinicians and radiologists being aware of the significance of the clinical presentation and MRI findings, meaning that this likely represents an incomplete survey of the AFM cases presenting in this population during this period, as even those who were eventually diagnosed with AFM were given a multitude of other diagnoses first.

Delayed diagnosis or misdiagnosis of this condition as psychogenic weakness or orthopaedic illness was not uncommon. The rarity of this diagnosis and changing nosology for this 
condition may contribute to delay in diagnosis, leading to inappropriate investigations and treatments and hindering our ability to identify future outbreaks and define the prevalence of AFM. Improved clarity in nomenclature and increased awareness of this condition will help address these issues.

\section{Conclusion}

AFM is a rare entity comprised of limb weakness in the context of anteriorly/gray matter predominant myelitis as found on MRI, with or without cranial nerve involvement. This cohort provides clinical data consistent with previous findings and demonstrates that persistent weakness and disability are relatively common in children affected by AFM. This condition should be suspected in the setting of acute limb pain associated with a lower motor neuron pattern of weakness.

\section{References}

[1]. Nelson GR, Bonkowsky JL, Doll E, et al. Recognition and Management of Acute Flaccid Myelitis in Children. Pediatr Neurol. 2016 55: 17-21.

[2]. Messacar K, Schreiner TL, Maloney JA, et al. A cluster of acute flaccid paralysis and cranial nerve dysfunction temporally associated with an outbreak of enterovirus D68 in children in Colorado, USA. Lancet. 2015.

[3]. Sejvar J, Pastula D, Cortese M, et al. Acute flaccid myelitis: interim considerations for clinical management. Atlanta, GA: US Department of Health and Human Services, $C D C$ Available at: http://www.cdc.gov/acute-flaccid-myelitis/downloads/acuteflaccid-myelitis.pdf (accessed 21 September 2016). 2014.

[4]. Teoh HL, Mohammad SS, Britton PN, et al. Clinical Characteristics and Functional Motor Outcomes of Enterovirus 71 Neurological Disease in Children. JAMA Neurol. 2016 73: 300-307.

[5]. CDC. Case Definition of AFM. Available at: http://www.cdc.gov/acute-flaccidmyelitis/hcp/case-definition.html (accessed 21 September 2016). 2016.

[6]. Yiu EM, Burns J, Ryan MM, Ouvrier RA. Neurophysiologic abnormalities in children with Charcot-Marie-Tooth disease type 1A. J Peripher Nerv Syst. 2008 13: 236-241. 
[7]. Dyck PJ, Boes CJ, Mulder D, et al. History of standard scoring, notation, and summation of neuromuscular signs. A current survey and recommendation. $J$ Peripher Nerv Syst. 2005 10: 158-173.

[8]. Huang CC, Liu CC, Chang YC, Chen CY, Wang ST, Yeh TF. Neurologic complications in children with enterovirus 71 infection. N Engl J Med. 1999 341: 936-942.

[9]. Defresne P, Meyer L, Tardieu M, et al. Efficacy of high dose steroid therapy in children with severe acute transverse myelitis. J Neurol Neurosurg Psychiatry. 2001 71: $272-274$.

[10]. Bogdanov IL, IaM B, Dubinskaia KO, Alekseeva NV. [Use of corticosteroids in acute stages of poliomyelitis and in other neuroinfections]. Pediatr Akus Ginekol. 1962 1: 9-11.

[11]. Findlay GM, Howard EM. The effects of cortisone and adrenocorticotrophic hormone on poliomyelitis and on the other virus infections. J Pharm Pharmacol. 1952 4: 3742.

[12]. Nolan MA, Craig ME, Lahra MM, et al. Survival after pulmonary edema due to enterovirus 71 encephalitis. Neurology. 2003 60: 1651-1656.

[13]. Leis AA, Stokic DS. Neuromuscular manifestations of west nile virus infection. Front Neurol. 2012 3: 37.

[14]. Yu P, Gao Z, Zong Y, et al. Distribution of enterovirus 71 RNA in inflammatory cells infiltrating different tissues in fatal cases of hand, foot, and mouth disease. Arch Virol. 2015 160: 81-90.

[15]. Hopkins IJ. A new syndrome: poliomyelitis-like illness associated with acute asthma in childhood. Aust Paediatr J. 1974 10: 273-276.

[16]. Arita J, Nakae Y, Matsushima H, Maekawa K. Hopkins syndrome: T2-weighted high intensity of anterior horn on spinal MR imaging. Pediatr Neurol. 1995 13: 263-265.

[17]. Yeung SC, Antonio G, Ip KS. Flaccid paralysis of the limbs after an asthmatic attack. Pediatr Neurol. 2010 42: 133-136. 
[18]. Bogoch, II, Wilson MR, Chad DA, Venna N. Acute lower motor neuron syndrome and spinal cord gray matter hyperintensities in HIV infection. Neurol Neuroimmunol Neuroinflamm. 2015 2: e113.

\section{Figure 1: MRI spine}

Axial T2-weighted images demonstrate increased signal in the region of the anterior horns at the lower thoracic (A, case 4; D, case 8) and cervical regions (C, case 8; F, case 6). Increased signal could be unilateral (A, C, D) or bilateral (F). Post-contrast axial T1-weighted image demonstrates ventral nerve root enhancement (B, case 4). Sagittal T2-weighted images demonstrate the extent of signal changes ventrally (E, case 6; G, case 7).

Table 1: Clinical characteristics, treatment and follow up

\begin{tabular}{|c|c|c|c|c|c|c|c|c|}
\hline $\begin{array}{l}\text { Case } \\
\text { No. }\end{array}$ & 1 & 2 & 3 & 4 & 5 & 6 & 7 & 8 \\
\hline $\begin{array}{l}\text { Age } \\
\text { at } \\
\text { onse } \\
\mathrm{t}\end{array}$ & $\begin{array}{c}8 \\
\text { years }\end{array}$ & 6 years & $\begin{array}{c}21 \\
\text { months }\end{array}$ & 4 years & $\begin{array}{c}14 \\
\text { months }\end{array}$ & 6 years & 7 years & $\begin{array}{c}3 \\
\text { mont } \\
\text { hs }\end{array}$ \\
\hline Sex & $\begin{array}{c}\text { Femal } \\
\mathrm{e}\end{array}$ & Female & Female & Male & Female & Female & Female & Male \\
\hline $\begin{array}{l}\text { Infec } \\
\text { tious } \\
\text { prod } \\
\text { rome }\end{array}$ & $\begin{array}{c}\text { Viral } \\
\text { URTI } \\
\text { with } \\
\text { asthm } \\
\text { a }\end{array}$ & $\begin{array}{l}\text { Fever, } \\
\text { gastroen } \\
\text { teritis }\end{array}$ & $\begin{array}{l}\text { Viral } \\
\text { URTI }\end{array}$ & $\begin{array}{c}\text { Viral } \\
\text { URTI } \\
\text { with } \\
\text { asthma }\end{array}$ & $\begin{array}{c}\text { Fever, } \\
\text { gastroente } \\
\text { ritis }\end{array}$ & $\begin{array}{c}\text { Viral } \\
\text { URTI }\end{array}$ & $\begin{array}{c}\text { Viral } \\
\text { URTI }\end{array}$ & $\begin{array}{c}\text { Feve } \\
\mathrm{r} \\
\text { with } \\
\text { out } \\
\text { local } \\
\text { ising }\end{array}$ \\
\hline
\end{tabular}




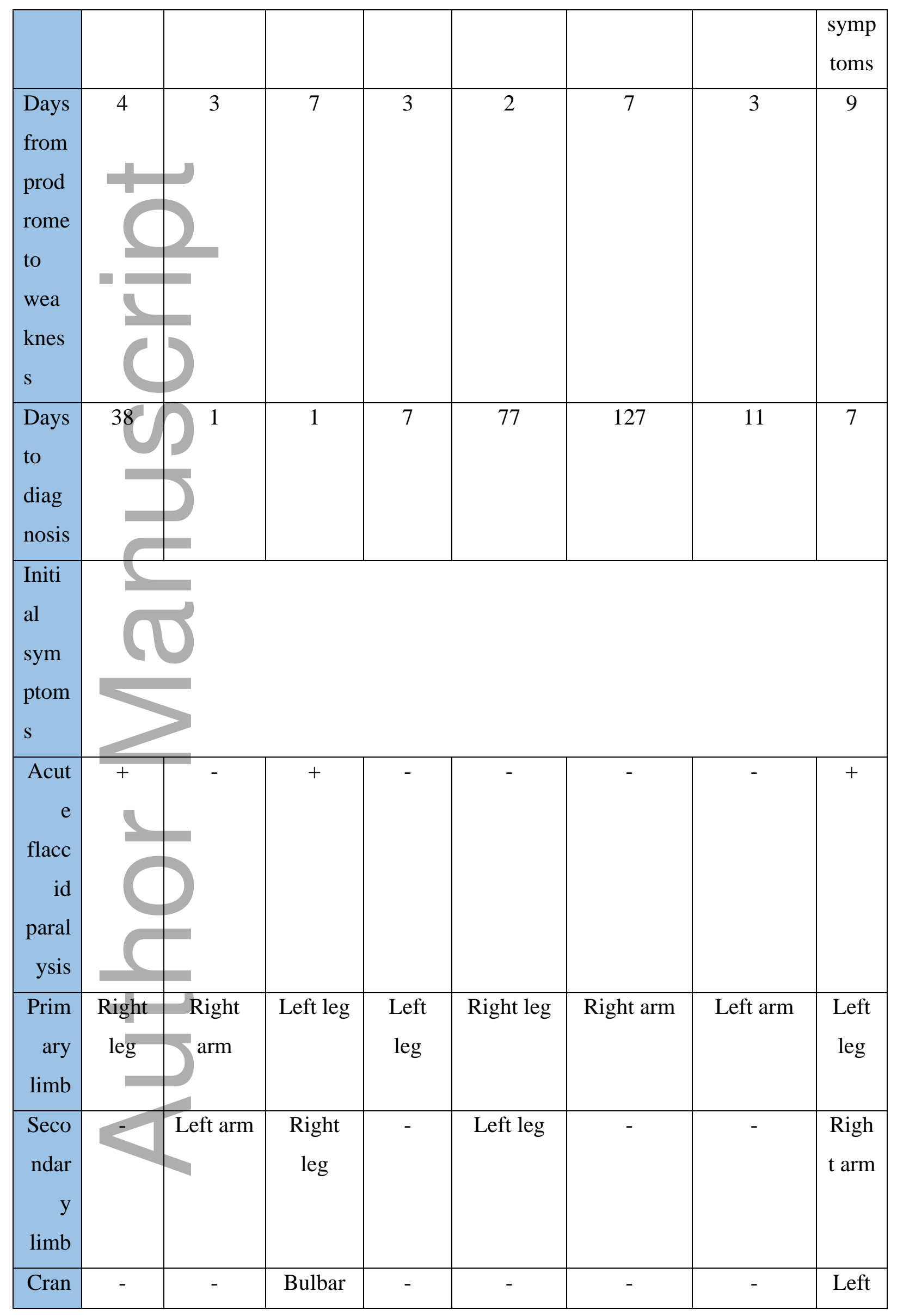

This article is protected by copyright. All rights reserved 


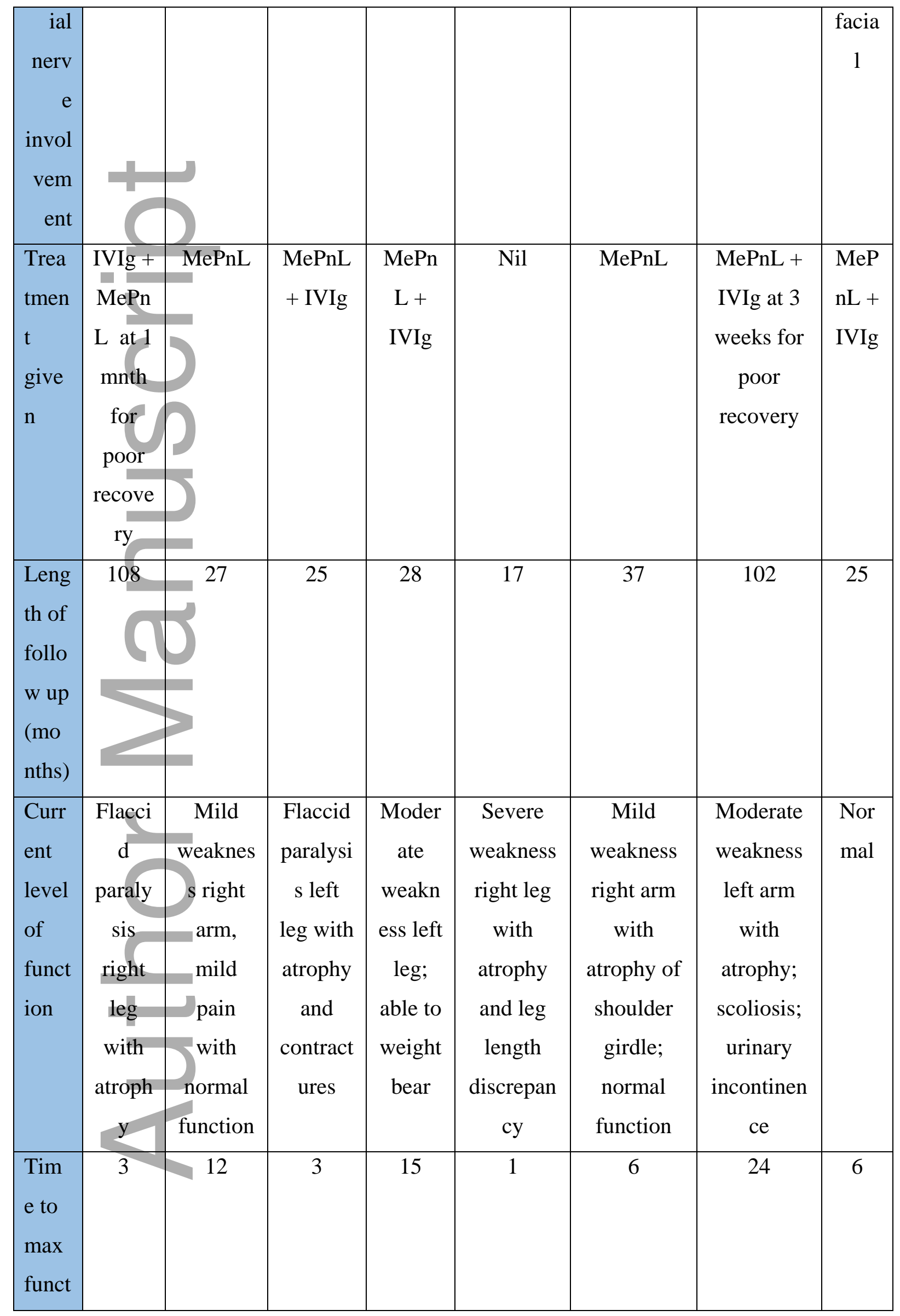




\begin{tabular}{|l|l|l|l|l|l|l|l|l|}
\hline $\begin{array}{l}\text { ion } \\
\text { (mo } \\
\text { nths) }\end{array}$ & & & & & & & & \\
\hline
\end{tabular}

MePnL: methylprednisolone

IVIg: intravenous immunoglobulin

Table 2: Investigations

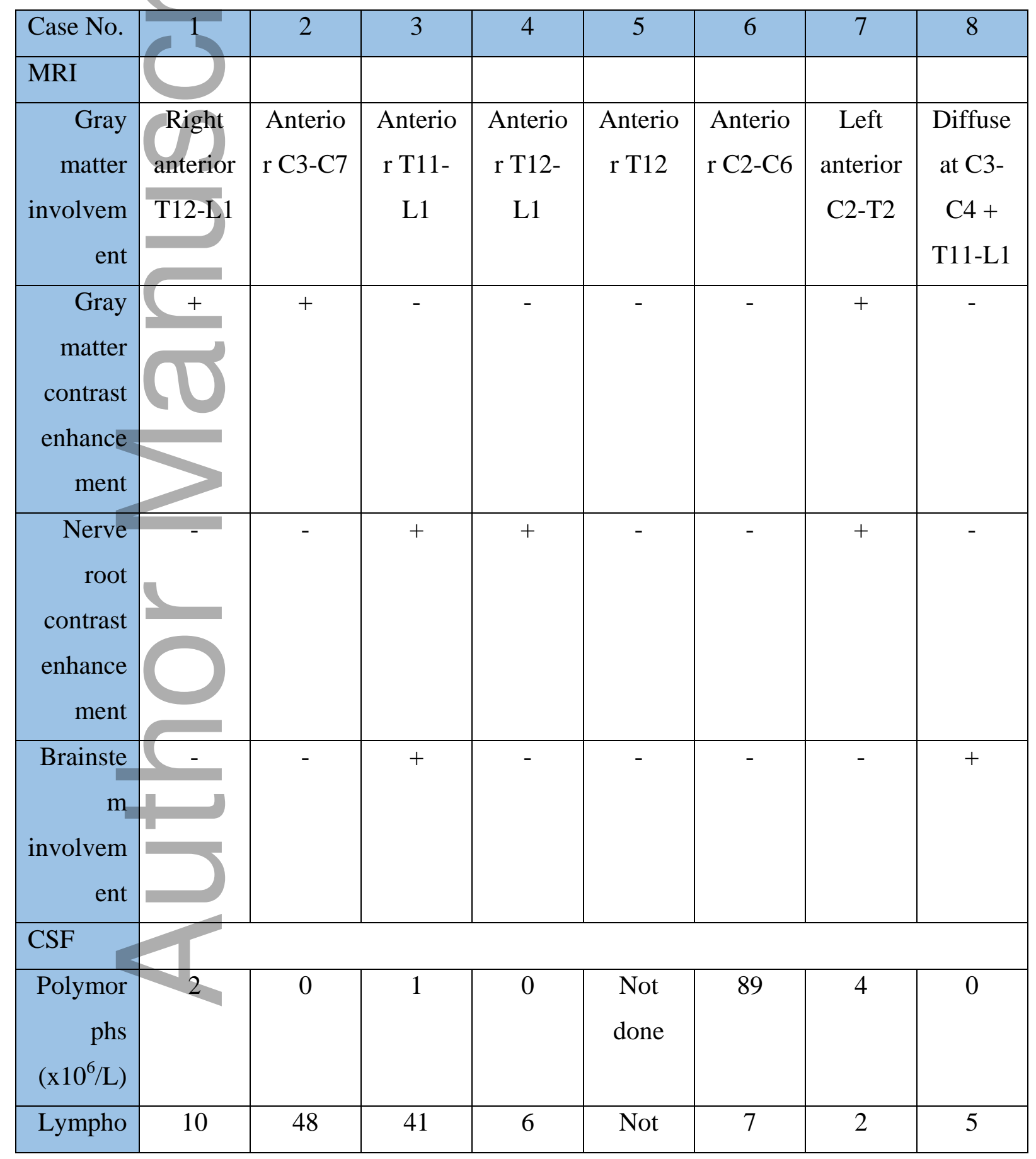




\begin{tabular}{|c|c|c|c|c|c|c|c|c|}
\hline $\begin{array}{r}\text { cytes } \\
\left(\times 10^{6} / \mathrm{L}\right)\end{array}$ & & & & & done & & & \\
\hline $\begin{array}{r}\text { Erythroc } \\
\text { ytes } \\
\left(\mathrm{x} 10^{6} / \mathrm{L}\right.\end{array}$ & J & 3 & 3 & 0 & $\begin{array}{l}\text { Not } \\
\text { done }\end{array}$ & $>9999$ & 1 & 15 \\
\hline $\begin{array}{r}\begin{array}{r}\text { Protein } \\
(\mathrm{g} / \mathrm{L}\end{array} \\
\text { Referenc } \\
\text { e Range } \\
0.2-0.4)\end{array}$ & 0.67 & 0.33 & 0.77 & 0.51 & $\begin{array}{l}\text { Not } \\
\text { done }\end{array}$ & 0.71 & 0.32 & 0.84 \\
\hline $\begin{array}{l}\text { NCS } \\
\text { (days } \\
\text { from } \\
\text { symptom } \\
\text { s to } \\
\text { study) }\end{array}$ & (38 & $\begin{array}{l}\text { Not } \\
\text { done }\end{array}$ & (1 day) & (7 days) & $\begin{array}{l}77 \\
\text { days })\end{array}$ & $\begin{array}{c}\text { Not } \\
\text { done }\end{array}$ & $\begin{array}{c}\text { (11 } \\
\text { days) }\end{array}$ & (7 days) \\
\hline CMAPs & Absent & N/A & $\begin{array}{c}\text { Low } \\
\text { amplitu } \\
\text { de, CV } \\
\text { normal }\end{array}$ & Normal & Normal & N/A & Absent & Normal \\
\hline SNAPs & Normal & N/A & Normal & Normal & Normal & N/A & Normal & Normal \\
\hline EMG & $\begin{array}{l}\text { Not } \\
\text { done }\end{array}$ & $\begin{array}{l}\text { Not } \\
\text { done }\end{array}$ & & & & $\begin{array}{l}\text { Not } \\
\text { done }\end{array}$ & & \\
\hline $\begin{array}{r}\text { Active } \\
\text { denervati } \\
\text { on }\end{array}$ & & N/A & - & + & - & N/A & + & - \\
\hline $\begin{array}{r}\text { Polyphas } \\
\text { ia }\end{array}$ & N/A & N/A & - & $\begin{array}{c}\text { Increas } \\
\text { ed }\end{array}$ & $\begin{array}{c}\text { Mildly } \\
\text { increase } \\
\mathrm{d}\end{array}$ & N/A & $\begin{array}{c}\text { Increas } \\
\text { ed }\end{array}$ & $\begin{array}{c}\text { Mildly } \\
\text { increase } \\
\text { d }\end{array}$ \\
\hline $\begin{array}{r}\text { Amplitu } \\
\text { de }\end{array}$ & $\mathrm{N} / \mathrm{A}$ & N/A & Normal & High & High & N/A & High & High \\
\hline $\begin{array}{r}\text { Recruitm } \\
\text { ent }\end{array}$ & N/A & N/A & $\begin{array}{c}\text { Decreas } \\
\text { ed }\end{array}$ & $\begin{array}{c}\text { Decreas } \\
\text { ed }\end{array}$ & $\begin{array}{c}\text { Decreas } \\
\text { ed }\end{array}$ & N/A & $\begin{array}{c}\text { Decreas } \\
\text { ed }\end{array}$ & $\begin{array}{c}\text { Decreas } \\
\text { ed }\end{array}$ \\
\hline
\end{tabular}


CMAPs: Compound muscle action potentials

SNAPs: Sensory nerve action potentials

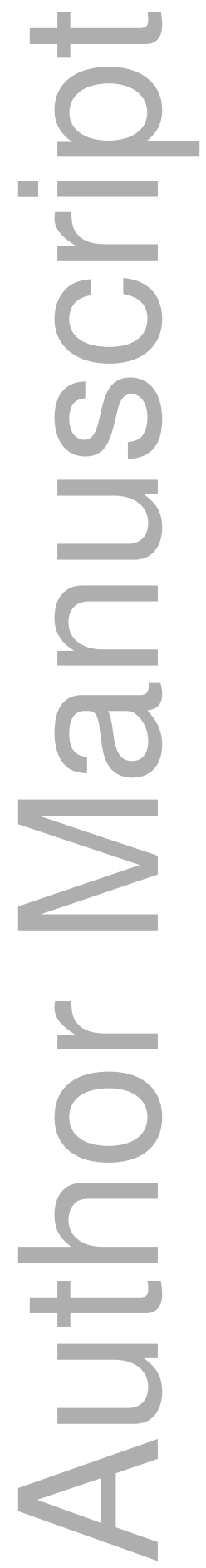

This article is protected by copyright. All rights reserved 

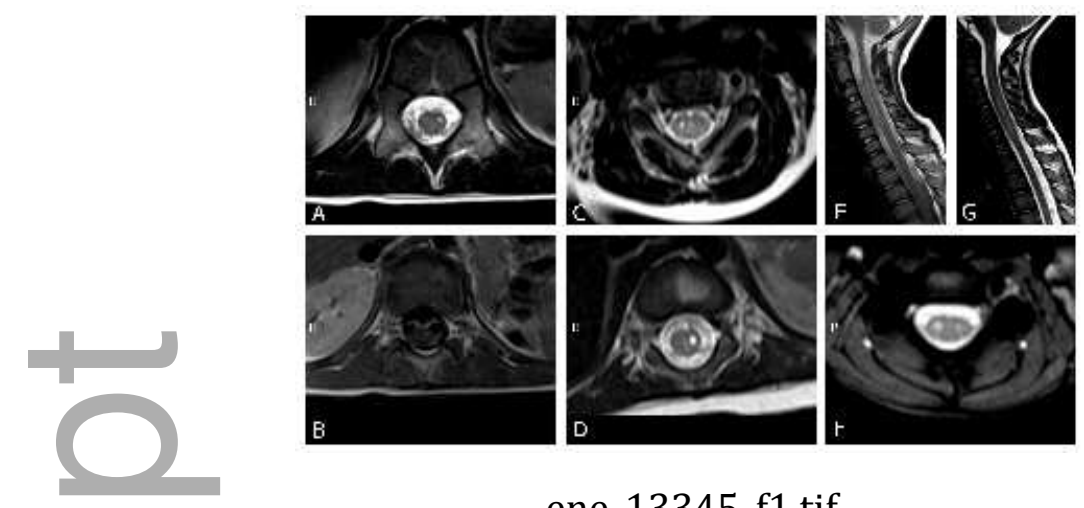

$\square$
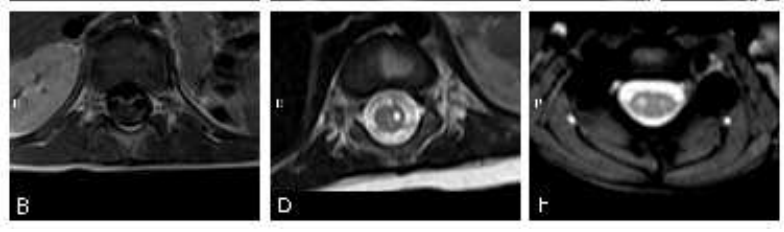

ene_13345_f1.tif
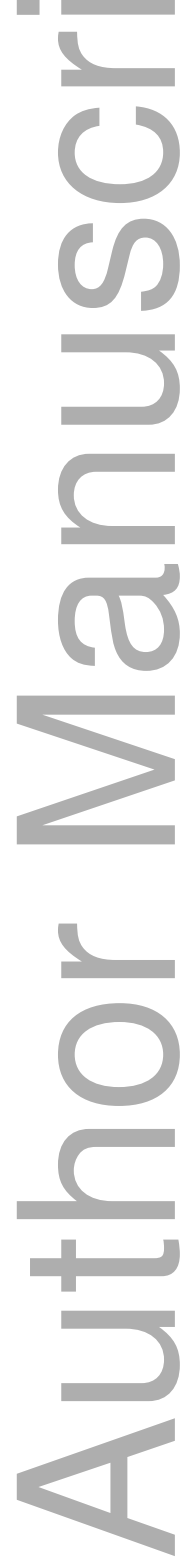

This article is protected by copyright. All rights reserved 


\section{University Library}

\section{- M M I N E R VA A gateway to Melbourne's research publications}

Minerva Access is the Institutional Repository of The University of Melbourne

Author/s:

Andersen, EW;Kornberg, AJ;Freeman, JL;Leventer, RJ;Ryan, MM

Title:

Acute flaccid myelitis in childhood: a retrospective cohort study

Date:

2017-08-01

Citation:

Andersen, E. W., Kornberg, A. J., Freeman, J. L., Leventer, R. J. \& Ryan, M. M. (2017).

Acute flaccid myelitis in childhood: a retrospective cohort study. EUROPEAN JOURNAL OF NEUROLOGY, 24 (8), pp.1077-1083. https://doi.org/10.1111/ene.13345.

Persistent Link:

http://hdl.handle.net/11343/293098 